\title{
Technologies to Enhance Operation of the Existing Natural Gas Compression Infrastructure
}

\author{
Quarterly Technical Progress Report \\ Reporting Period Start Date: 01/01/03 \\ Reporting Period End Date: 03/31/03
}

\author{
Principal Authors: \\ Anthony J. Smalley \\ Ralph E. Harris
}

\begin{abstract}
April 2003
DOE Award No. DE-FC26-02NT41646

SwRI Project No. 18.06223
\end{abstract}

Submitting Organization:

Southwest Research Institute ${ }^{\circledR}$

6220 Culebra Road

San Antonio, TX 78238-5166 


\section{DISCLAIMER}

"This report was prepared as an account of work sponsored by an agency of the United States Government. Neither the United States Government nor any agency thereof, nor any of their employees, makes an warranty, express or implied, or assumes any legal liability or responsibility for the accuracy, completeness, or usefulness of any information, apparatus, product, or process disclosed, or represents that its use would not infringe privately owned rights. Reference herein to any specific commercial product, process, or service by trade name, trademark, manufacturer, or otherwise does not necessarily constitute or imply its endorsement, recommendation, or favoring by the United States Government or any agency thereof. The views and opinions of authors expressed herein do not necessarily state or reflect those of the United States Government or any agency thereof." 


\section{ABSTRACT}

This report documents work performed in the second quarter of the project entitled: Technologies to Enhance Operation of the Existing Natural Gas Compression Infrastructure. The project objective is to develop and substantiate methods for operating integral engine/compressors in gas pipeline service, which reduce fuel consumption, increase capacity, and enhance mechanical integrity. The report describes the following work: preparation and submission of the Technology Status Assessment; formation of the Industry Advisory Committee (IAC) for the project; attendance at the first IAC meeting; preparation of the Test Plan; completion of the data acquisition system (DAS); plans for the first field test. 


\section{TABLE OF CONTENTS}

Page

1. INTRODUCTION............................................................................................ 1

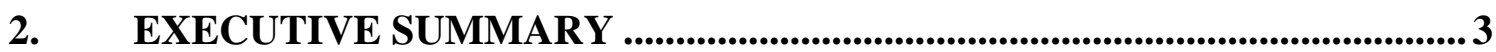

3. EXPERIMENTAL .................................................................................................. 4

4. RESULTS AND DISCUSSION .........................................................................5

RESEARCH MANAGEMENT PLAN (TASK 1) …………………………………….

TECHNOLOGY STATUS ASSESSMENT (TASK 2).................................................

INDUSTRY ADVISORY COMMITTEE (TASK 3) ...................................................

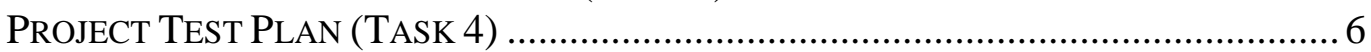

DATA ACQUISITION SYSTEM (TASK 5) ........................................................

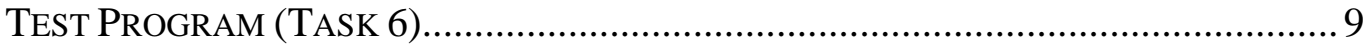

5. CONCLUSIONS ..................................................................................................10

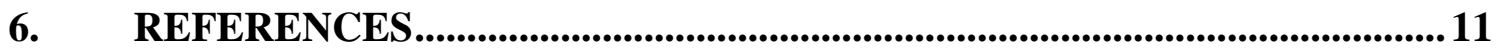

7. LIST OF ACRONYMS AND ABBREVIATIONS .......................................... 12 


\section{LIST OF TABLES}

Page

Table 1. High Count ENGines IN Gas Transmission - Sorted by Number

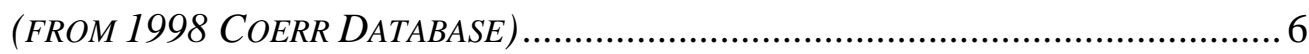

TABle 2. High Count ENGines In Gas TRANSMission - Sorted by HORSEPOWER (FROM 1998 COERR DATABASE) ………................................ 7

\section{LIST OF FIGURES}

$\underline{\text { Page }}$

FIGURE 1. FRONT VIEW OF DATA ACQUISITION SYSTEM (DAS) .................................. 8

FIGURE 2. REAR VIEW OF DATA ACQUISITION SYSTEM (DAS) ................................... 8 


\section{INTRODUCTION}

This report documents work performed in the second quarter (January 2003 through March 2003) of the project entitled: Technologies to Enhance Operation of the Existing Natural Gas Compression Infrastructure.

The project objective is to develop and substantiate methods for operating integral engine/compressors in gas pipeline service, which reduce fuel consumption, increase capacity, and enhance mechanical integrity.

The project has been structured in three phases - the first to last eighteen (18) months, with nine (9) tasks. These tasks, with their objectives, are as follows:

1. Research Management Plan: To define a work breakdown structure and supporting narrative that addresses the overall project objectives.

2. Technology Status Assessment: To describe current and competing technologies for pipeline compression, with strengths and weaknesses.

3. Industry Advisory Committee (IAC): To interact with industry advisors and their suppliers and, thereby, focus the work and help transfer knowledge into practice.

4. Test Plan: To develop a test plan which addresses project objectives, and which will serve as a basis for tests to be performed at various industry sites.

5. Data Acquisition System (DAS): To develop a data system which will support project objectives and acquire all needed data with appropriate format, data rates, and display.

6. Test Program: To perform tests on a representative series of engine/compressors; gather data to develop required relationships for efficiency, capacity, and mechanical integrity.

7. Data Analysis: To relate power cylinder standard deviation, balancing process, and compressor cylinder operation to fuel flow, compression efficiency, and crankshaft strain through models.

8. Methods for Optimized Operation: To apply the models and develop optimized methods for balancing and operating engine/compressors.

9. Program Management: To perform planning, administrative, and technical direction functions to achieve project objectives; to communicate with and report to the DOE and other co-funding organizations. 
So far, progress has been made under Tasks 1 through 6 and Task 9, and is discussed in the subsequent sections of this quarterly report.

In the first quarter, Task 1 was completed, and progress was made on Tasks 2, 3, 4, 5, and 9.

In the second quarter, Tasks 2, 4, and 5 were completed; further progress was made on Tasks 3 and 9, and initial progress was made on Task 6 (calibration site visit for first test site).

The first test under Task 6 is scheduled for the third week of April, and will be reported in the third quarterly report. 


\section{EXECUTIVE SUMMARY}

Southwest Research Institute ${ }^{\circledR}$, s (SwRI ${ }^{\circledR}$ ) Research Management Plan for the project was prepared and submitted to DOE in the first quarter. This completes project Task 1.

A Technology Status Assessment document was completed and was submitted to DOENETL in the second quarter. This completes project Task 2.

An Industry Advisory Committee (IAC) was formed in the first quarter. A first IAC meeting was held January 14, 2003, and provided valuable project direction. This activity falls under project Task 3 .

The project Test Plan was completed in the second quarter, reviewed by the Industry Advisory Committee, and submitted to DOE-NETL. This completes project Task 4.

Physical construction of the data acquisition system was completed in the second quarter, together with adaptation of existing data acquisition software to the specific needs of the project. The complete data acquisition system was checked out with transducers, and made ready for use on the first field test, scheduled for the week of April 14, 2003. This completes project Task 5 .

In preparation for the first field test under Task 6, a site visit to the test site was conducted in early February. This visit helped with specific selection of the test unit, familiarization of project staff with site and protocols, and with briefing of host staff with the project goals, needs for access to the unit, and planned test sequences. In addition, the transducers were calibrated. This represents progress under Task 6.

The first field test will be held at El Paso Corporation's Station 823 in Kinder, Louisiana. The test unit will be a Clark HBA6.

The following report discusses each of these items of progress in more detail. 


\section{EXPERIMENTAL}

As described in the Test Plan, the following data channels will be acquired simultaneously and processed as part of the testing:

- Compressor cylinder dynamic pressure - used for compressor horsepower and flow determination (Sensotec piezo-restrictive transducer).

- Engine dynamic cylinder pressure - used for engine horsepower determination, engine balance, and engine statistics (Kistler quartz piezoelectric transducer).

- Engine intake and exhaust dynamic pressure measurements - used to correlate acoustic dynamic effects to engine statistics (Kistler piezo-restrictive transducer (water-cooled)).

- Torsional vibrations (IRV) - used as a surrogate for mechanical integrity (BEI 512 pulse encoder).

- Bearing centerline vibration measurements - used as a surrogate for mechanical integrity (PCB velocimeters).

- Crankshaft dynamic strain - acquired using SwRI's Strain Data Capture Module (SDCM). Used as a direct measurement of shaft loading, and used to provide link between engine statistical quantities (PFP), and crankshaft fatigue damage [Ref. 1].

- Engine fuel flow - used to document overall engine efficiency (AGA3 method using Emerson Flobas 103).

- Suction header and discharge header pressures and temperatures - used for installation efficiency determination (Sensotec piezo-restrictive transducer).

- Engine exhaust $\mathrm{NO}_{\mathrm{X}}$ and $\mathrm{O}_{2}$ levels - used for input into an engine performance model (NGK fast-response transducer).

- Compressor rod load - used for both mechanical integrity and loading optimization (strain gage-based; bridged to cancel bending). 


\section{RESULTS AND DISCUSSION}

\section{Research Management Plan (TASk 1)}

Completed in first quarter.

\section{Technology Status Assessment (TASK 2)}

The Technology Status Assessment document defines the new technologies to be applied or developed under the project. These are:

- The Strain Data Capture Module (SDCM)

- Rod Load Monitoring (RLM)

- Alternative Power Cylinder Balancing Methodologies

- Cylinder Loading Control

- Speed Control

- Operational Optimization

This five-page document describes each technology briefly with illustrative photographs, where appropriate; it identifies competing technologies; it identifies the benefits of the new technology in comparison to the competing technology. The technology status assessment document was submitted to DOE-NETL in January 2003. This completes Task 2 .

\section{IndUSTRY AdVISORY COMMITTEE (TASK 3)}

An Industry Advisory Committee (IAC) was formed in the first quarter and a first meeting was held January 14, 2003 at El Paso Corporation's offices in Houston at 9 Greenway Plaza. Committee members are:

- Sam Clowney, El Paso Corporation, GMRC/PRCI Chairman, Champion

- Rondle Harp, DOE-NETL, Project Manager

- Randy Raymer, El Paso Corporation

- Carl Williams, Duke Energy

- Bruce Howerton, Williams Gas Pipeline

At present, committee members represent all those operating companies who have offered test sites. In addition, the project champion from GMRC/PRCI and the DOE project manager are members. 
This meeting served to introduce all IAC members and SwRI project team members; to introduce the project plans to IAC members; to provide a forum for critical, interactive appraisal of project goals and plans by knowledgeable industry representatives; to establish channels for communication between project team and IAC; and to prioritize sites for the first two tests. Important consensus from the meeting was:

- The Committee Chairman will be Sam Clowney.

- Technical communications from the project should be reviewed by the IAC before formal submittal.

- Subject to this review, data acquired under the project would include emissions.

- The project should not have emissions control as a primary goal, but should recognize emissions limits as a constraint to be considered in optimization of performance.

- First choice for the first test site would be Williams' El Campo site (GMW), which combines close proximity to San Antonio with the highest population engine in the gas transmission fleet.

- If the El Campo site could not be scheduled, the second choice was El Paso's Kinder station. This combined acceptable proximity and the fourth highest population twostroke engine in the gas transmission fleet. (This site was eventually selected as the first test site; the second will be a GMW at the Williams' El Campo site.)

In general, data obtained during the project will be an important input in guiding project direction.

\section{Project Test Plan (Task 4)}

The Project Test Plan was drafted and submitted to the Industry Advisory Committee (IAC) for review. Following this review, the plan was submitted to DOE-NETL. The test plan includes selection of candidate engine/compressor models and test sites. Data to support this analysis was obtained from an industry database of engines and compressors in gas transmission service, supported by PRCI. Tables 1 and 2 were obtained by appropriate sorting of the database to show the top ten (10) engine models in terms of number installed (Table 1) and in terms of horsepower installed (Table 2). These rankings were one input guiding the choice of engine.

Table 1. High Count Engines in Gas Transmission - Sorted by Number (from 1998 Coerr Database)

\begin{tabular}{|c|c|c|c|c|c|c|}
\hline Model & Sum of Rated HP & Count & Cumulative & & & Comments \\
\hline GMW & 708336 & 336 & 336 & Top 6 by HP or \# & Top 10 by HP or \# & Just GMW - No GMWA \& GMWC \\
KVG & 330918 & 296 & 632 & & Top 10 by HP or \# & \\
TLA & 672085 & 280 & 912 & Top 6 by HP or \# & Top 10 by HP or \# & \\
GMV & 270489 & 269 & 1181 & & Top 10 by HP or \# & Just GMV - No GMVB \& GMVH \\
KVS & 441455 & 233 & 1414 & Top 6 by HP or \# & Top 10 by HP or \# & \\
HBA & 372414 & 223 & 1637 & Top 6 by HP or \# & Top 10 by HP or \# & \\
GMVH & 302242 & 179 & 1816 & & Top 10 by HP or \# & \\
TCV & 872106 & 155 & 1971 & & Top 10 by HP or \# & Includes TCV thru TCVD \\
L-7042 & 154528 & 150 & 2121 & & & Small High-Speed Waukesha \\
BA & 207271 & 140 & 2261 & & & Old \& Small \\
\hline
\end{tabular}


Table 2. High Count Engines in Gas Transmission - Sorted by Horsepower (from 1998 Coerr Database)

\begin{tabular}{|c|c|c|c|c|c|c|}
\hline Model & Sum of Rated HP & Count & Cumulative HP & & Comments \\
\hline TCV & 872106 & 155 & 872106 & & Top 10 by HP or \# & High HP \\
GMW & 708336 & 336 & 1580442 & Top 6 by HP or \# & Top 10 by HP or \# & \\
TLA & 672085 & 280 & 2252527 & Top 6 by HP or \# & Top 10 by HP or \# & \\
KVS & 441455 & 233 & 2693982 & Top 6 by HP or \# & Top 10 by HP or \# & \\
HBA & 372414 & 223 & 3066396 & Top 6 by HP or \# & Top 10 by HP or \# & \\
V-250 & 335450 & 93 & 3401846 & & & \\
KVG & 330918 & 296 & 3732764 & & Top 10 by HP or \# & \\
W-330 & 315656 & 56 & 4048420 & & & High HP; Recent \\
GMVH & 302242 & 179 & 4350662 & & Top 10 by HP or \# & \\
GMV & 270489 & 269 & 4621151 & & Top 10 by HP or \# & \\
\hline Note: If we total all GMV, GMVB, GMVC thru GMVS, we get 962,510 HP and 721 units. & & \\
\hline
\end{tabular}

The test plan includes the data channels documented in the Experimental section of this report. The test plan also documents the planned tests to be undertaken. The test plan also presents the planned test program, which is summarized below:

- Determination of engine characteristics and engine performance statistics as a function of compressor operation. This will be achieved by varying unit horsepower at constant speed and mapping engine characteristics for different compressor load steps. Horsepower changes will be achieved by varying unit ratio.

- Determination of engine and compressor performance characteristics and statistics as a function of engine speed and compressor loading. This will document changes in compressor performance as a function of unit speed and operation.

- Determination of engine characteristics, performance, engine statistics, and integrity metrics as a function of engine balance and balance methodology. This will examine engine balancing approaches and the ability to control integrity metrics, and affect engine statistical quantities.

\section{Data ACQUisition SYSTEm (TASK 5)}

Figures 1 and 2 show photographs of the Data Acquisition System (DAS). The system comprises an industrially hardened computer, a flat screen for display, and a separate box with connectors to which cables from individual sensors are connected. The DAS box has analog-to-digital converters of appropriate speed for over 50 different channels. 


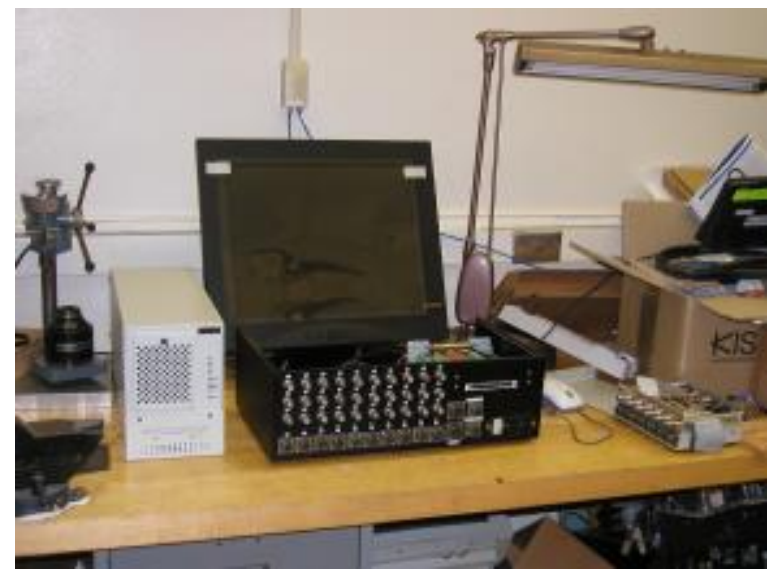

Figure 1. Front View of Data Acquisition System (DAS)

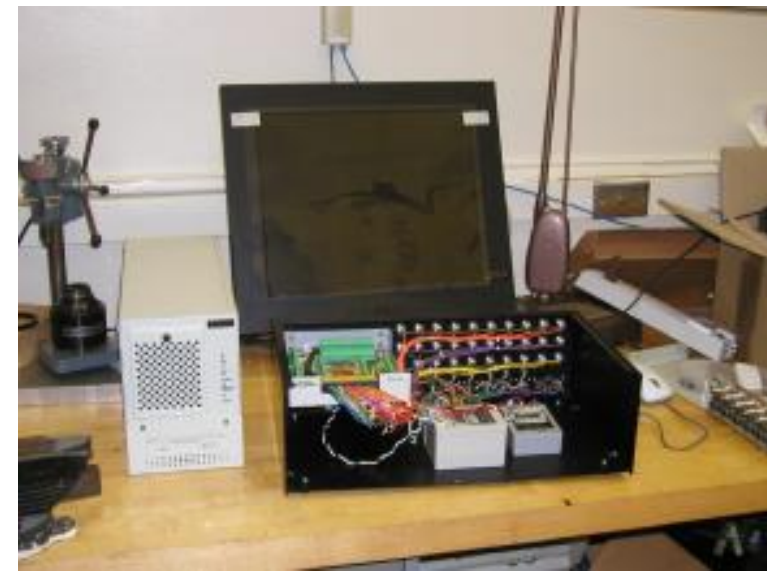

Figure 2. Rear View of Data Acquisition System (DAS)

To supplement the DAS, SwRI (as part of its capital equipment) has purchased a set of pressure transducers which will enable concurrent real-time dynamic pressure measurement in all the engine and compressor cylinders of most integral engine compressors.

The individual power cylinder transducers (up to 10) will be connected to a box with connectors on the deck near the cylinders. A single cable from this box will carry the signals from all the power cylinder transducers to the main data acquisition box. A similar approach will be used for the compressor cylinders. In this way, the complexity of the cabling and system checkout is minimized. Signals from rod load monitors, from other system pressures, and from temperature sensors will be acquired by the DAS, concurrently, and a database of the sensor values throughout the test will be created by the DAS.

The data acquisition system was completed in the second quarter. All hardware was assembled. All existing data acquisition software was adapted to the particular needs of the project. All channels were tested with the transducers. 


\section{Test Program (TASK 6)}

In early February, Ralph Harris and Gary Bourn (who will perform the tests) made a site visit to El Paso Corporation's Kinder site, Station 823. Station personnel were present, together with Randy Raymer from El Paso's offices in Houston, who has helped with test site arrangements. At this visit, the specific unit to be tested (an HBA6) was selected. This visit is designed to eliminate any misconceptions about the test and to ensure good two-way communication between project team and host personnel. 


\section{CONCLUSIONS}

The project continues to proceed with acceptable deviation from the plan. There has been slight slippage of the schedule to ensure availability of the test unit and needed personnel for the first test (now scheduled for the week of April 14, as opposed to completion in March, as originally planned). It is presently anticipated this slippage can be made up in the Tasks 7 and 8 efforts (Data Analysis and Methods for Optimized Operation). Tasks 1, 2, 4, and 5 are now complete. The first test under Task 6 should be completed by April 20, 2003. 


\section{REFERENCES}

1. Harris, R.E., Edlund, C.E., Smalley, A.J., and Weilbacher, G., "Dynamic Crank Web Strain Measurements for Reciprocating Compressors," presented at the GMRC Gas Machinery Conference (GMC), October 2-4, 2000, Colorado Springs, Colorado. 


\section{LIST OF ACRONYMS AND ABBREVIATIONS}

$\begin{array}{ll}\text { 02 } & \text { Oxygen Molecule } \\ \text { AGA } & \text { American Gas Association } \\ \text { BEI } & \text { Manufacturer's Trade Name } \\ \text { DAS } & \text { Data Acquisition System } \\ \text { DOE } & \text { U.S. Department of Energy } \\ \text { GMRC } & \text { Gas Machinery Research Council } \\ \text { HBA6 } & \text { Clark Engine Model } \\ \text { IAC } & \text { Industry Advisory Committee } \\ \text { IRV } & \text { Instantaneous Rotational Velocity } \\ \text { NETL } & \text { National Energy Technology Laboratory } \\ \text { NGK } & \text { Manufacturer's Trade Name } \\ \text { NO } & \text { Oxides of Nitrogen } \\ \text { PCB } & \text { Manufacturer's Trade Name } \\ \text { PFP } & \text { Peak-Firing Pressure } \\ \text { PRCI } & \text { Pipeline Research Council International } \\ \text { RLM } & \text { Rod Load Monitor } \\ \text { SDCM } & \text { Strain Data Capture Module } \\ \text { SwRI }{ }^{\circledR} & \text { Southwest Research Institute }\end{array}$

